\title{
Precursors of September Arctic Sea-Ice Extent Based on Causal Effect Networks
}

\author{
Sha Li ${ }^{1}$, Muyin Wang ${ }^{2,3, *}$, Nicholas A. Bond ${ }^{2,3}$, Wenyu Huang ${ }^{1}{ }^{\circledR}$, Yong Wang ${ }^{1}$, \\ Shiming $\mathrm{Xu}{ }^{1}{ }^{1}$, Jiping Liu ${ }^{4}$, Bin Wang ${ }^{1,5}$ and Yuqi Bai ${ }^{1, *}$ \\ 1 Ministry of Education Key Laboratory for Earth System Modeling, Department of Earth System Science, \\ Tsinghua University, Beijing 100084, China; lis14@mails.tsinghua.edu.cn (S.L.); \\ huangwenyu@mail.tsinghua.edu.cn (W.H.); yongw@mail.tsinghua.edu.cn (Y.W.); \\ xusm@mail.tsinghua.edu.cn (S.X.); wab@tsinghua.edu.cn (B.W.) \\ 2 Joint Institute for the Study of the Atmosphere and Ocean, University of Washington, \\ Seattle, WA 98195, USA; nicholas.bond@noaa.gov \\ 3 Pacific Marine Environmental Laboratory, National Oceanic and Atmospheric Administration, \\ Seattle, WA 98115, USA \\ 4 Department of Atmospheric and Environmental Sciences, University at Albany, \\ State University of New York, Albany, NY 12222, USA; jliu26@albany.edu \\ 5 State Key Laboratory of Numerical Modeling for Atmospheric Sciences and Geophysical Fluid Dynamics \\ (LASG), Institute of Atmospheric Physics, Chinese Academy of Sciences, Beijing 100029, China \\ * Correspondence: muyin.wang@noaa.gov (M.W.); yuqibai@tsinghua.edu.cn (Y.B.); \\ Tel.: +1-206-526-4532 (M.W.); +86-10-6279-5269 (Y.B.)
}

Received: 1 October 2018; Accepted: 2 November 2018; Published: 9 November 2018

\begin{abstract}
Although standard statistical methods and climate models can simulate and predict sea-ice changes well, it is still very hard to distinguish some direct and robust factors associated with sea-ice changes from its internal variability and other noises. Here, with long-term observations (38 years from 1980 to 2017), we apply the causal effect networks algorithm to explore the direct precursors of September Arctic sea-ice extent by adjusting the maximal lead time from one to eight months. For lead time of more than three months, June downward longwave radiation flux in the Canadian Arctic Archipelago is the only one precursor. However, for lead time of 1-3 months, August sea-ice concentration in Western Arctic represents the strongest positive correlation with September sea-ice extent, while August sea-ice concentration factors in other regions have weaker influences on the marginal seas. Other precursors include August wind anomalies in the lower latitudes accompanied with an Arctic high pressure anomaly, which induces the sea-ice loss along the Eurasian coast. These robust precursors can be used to improve the seasonal predictions of Arctic sea ice and evaluate the climate models.
\end{abstract}

Keywords: precursors; causal effect networks; sea ice; Arctic

\section{Introduction}

Sea ice is one of the most important components of the polar climate system. It can impede the polar ocean from absorbing the solar radiation due to high albedo. Moreover, as the air-sea interface, sea ice can adjust and even preclude their exchange of heat, momentum, and materials (e.g., moisture, and $\mathrm{CO}_{2}$ ). The formation and ablation of sea ice not only affect the local salinity and stability, but also the global thermohaline system [1]. Although sea ice occupies a small fraction of earth area, its changes more or less have an impact on the local ecosystem and human activities in the sub-polar regions, even the extreme weather and climate in the low latitudes [2]. 
During the satellite era, Arctic sea-ice extent (SIE) has a downward trend in each month, decreasing most rapidly in September [3,4]. Both observations and models reveal that there are progressively larger variability and accelerated decline of Arctic sea ice in summer [5-7]. Since the early 21st century, a series of extreme September SIE minima have sprung up. The September SIE fell into the lowest value ( 3.57 million $\mathrm{km}^{2}$ ) in 2012, breaking the record of 4.27 million $\mathrm{km}^{2}$ set in 2007, as shown by the data published by the National Snow and Ice Data Center (NSIDC) [8]. The frequent occurrence of these minimal values also indicates the responses of Arctic sea ice to external forcing are enhanced [9].

Atmospheric thermodynamic forcing plays an important role in the melt of sea-ice cover through changes in surface temperature associated with the sensible and latent heat fluxes, or direct radiation forcings related to cloud cover change. Over the recent decades, variability in Arctic sea ice has been coupled to the surface warming [10]. There is a strong correlation between sea-ice decline and higher temperatures in spring, accelerating sea-ice melting [5,11-13]. In addition, Kay et al. [14] considered that the increased downward shortwave flux (DSF) associated with unusually clearer skies could make more ice melt with warmer surface ocean water, which had an important effect on the September sea ice record minimum in 2007. By contrast, using a coupled ice-ocean model (Pan-Arctic Ice-Ocean Modeling and Assimilation System (PIOMAS)) driven by National Center for Environmental Prediction (NCEP)/National Center for Atmospheric Research (NCAR) reanalysis atmospheric fields, Schweiger et al. [15] found that the sea ice minimum of 2007 was not significantly attributable to negative cloud anomaly in summer (June-August), and the impact of solar radiation in summer was small and just limited to the north of the ice edge. Furthermore, Graversen et al. [16] showed that the anomalously warm and humid air into the Arctic induced the positive anomalies of downwelling longwave flux (DLF) and turbulent fluxes, causing the 2007 extreme value. As demonstrated by Francis and Hunter [17], there was a strong positive correlation between summer ice retreats and DLF in different regions and the entire Arctic from 1979 to 2004, which overwhelmed the effect of DSF due to increases in higher clouds and atmospheric water vapor.

In turn, the loss of sea-ice cover has decreased the surface albedo and increased solar radiation flux into the upper ocean. The solar energy deposited in the sub-surface ocean could partly lead to the melt on the lateral edges or on the bottom of sea ice [18]. Perovich et al. [19] concluded that the observed enhanced bottom melting of sea ice within the Beaufort Sea in Summer 2007 to a large extent resulted from the earlier decline of SIE, inducing the positive ice-albedo feedback and the rapid ice retreat. Lindsay and Zhang [20] showed that the ice-albedo feedback has triggered the reduction of simulated ice thickness since 1988 with the thinner first-year ice in the following summer months. The recent abrupt thinning of sea ice also boosted the absorbed solar shortwave radiation and the open water formations through the positive ice-albedo feedback along with more ice export caused by anomalous atmospheric circulation, all of which led to the unprecedented sea-ice reduction in summer [21-23].

Besides these thermodynamic factors and natural variability of sea ice, atmospheric circulation anomalies have also accounted for the sharp decrease of sea ice through the response of ice motion to surface winds [4]. It is documented that between the late 1980s and mid-1990s, the sea-ice reductions were likely to be driven by the strong Arctic Oscillation (AO) positive phases in wintertime with Beaufort Gyre (anticyclonic ocean current in Western Arctic Ocean) weakened, promoting the ice divergence from Western Arctic to Eastern Arctic and ice export through Fram Strait [24-26]. Based on a simple model tracking ice age, Rigor and Wallace [27] showed, when winter AO index was in its high state, younger and thinner ice was transported back to the Alaskan coast quickly, which helped sea ice away from the Eurasian coast where thinner ice was vulnerable to melt the following spring and early summer. Additionally, a nine-year-long positive phase of Pacific Decadal Oscillation (PDO) ended in 1989 and shifted into a three-year-long negative phase with a weaker Beaufort Gyre, hastening the sea ice out of the Siberian sector of the basin [20]. As for the summer in 2007, L'Heureux et al. [28] studied the correlation between Pacific-North American (PNA) pattern and Arctic sea-ice reduction, and inferred with a high PNA index, the anomalously strong anti-cyclone (Beaufort High) where 
the loss of sea ice was greatest, accounted for the extreme sea-ice melting. Then, another findings indicated that a more meridional Arctic dipole atmospheric circulation structure, the second leading EOF (Empirical Orthogonal Function) mode of sea-level pressure north of $70^{\circ} \mathrm{N}$, contributed to more ice out of the Arctic Ocean into the North Atlantic [29-33]. However, the influence of these circulation regimes on sea ice, to some degree, depends on the study period [34,35].

While many likely reasons why the Arctic sea ice reduces substantially have been addressed and CMIP5 (Coupled Model Intercomparison Project Phase 5) simulations are closer to observed trends of sea ice than CMIP3, some considerable differences between observation and models are still detected, which make it hard to project the changes in sea-ice cover [6,36,37]. For one thing, it is difficult to express the complex physical processes in sea-ice models accurately. For another, it is unclear which players have a direct and robust relationship with sea-ice loss, regardless of internal variability and/or other noises. As for the latter, this study applies a novel data-driven approach named causal effect networks (CEN) to explore the preceding factors triggering the loss of September Arctic SIE. The essential merits of the method are to overcome some spurious correlations from common drivers or indirect links, determine the lead time of each precursor and identify the specific region with the most significant impacts on other regions [38].

\section{Materials and Methods}

\subsection{Data Sources}

Eighteen selected candidate factors are listed in Table 1, including: (1) observed sea-ice concentration (SIC); (2) model-based variables associated with sea-ice characters (sea-ice volume, sea-ice thickness, and zonal and meridional components of sea-ice velocity); (3) near-surface climate variables (sea surface temperature (SST), air temperature at 2-m height, downward surface longwave and shortwave radiation fluxes, net longwave and shortwave radiation fluxes on the surface, meridional temperature advection, sea-level pressure, zonal and meridional components of wind at 10-m height); and (4) climate indices representing atmospheric circulation patterns correlated with sea-ice change based on the previous studies (AO, PNA, PDO). Detrended anomalies were generated by removing long-term means and linear trends during the study period (1980-2017) in each calendar month for each variable, except for climate indices. Hereinafter, all of precursors represent the detrended anomalies unless specified.

Table 1. Candidate factors associated with September Arctic sea-ice extent.

\begin{tabular}{|c|c|c|c|}
\hline Name & Definition & Unit & Region \\
\hline SIC & Sea-ice concentration & $\%$ & Ice-covered ocean north of $30.98^{\circ} \mathrm{N}$ \\
\hline $\mathrm{SIV}^{1}$ & Sea-ice volume & $10^{3} \mathrm{~km}^{3}$ & \\
\hline SIT & Sea-ice thickness & $\mathrm{m}$ & Ice-covered ocean north of $49^{\circ} \mathrm{N}$ \\
\hline Uice & Zonal component of ice velocity & $\mathrm{m} / \mathrm{s}$ & Ice-covered ocean north of $49^{\circ} \mathrm{N}$ \\
\hline Vice & Meridional component of ice velocity & $\mathrm{m} / \mathrm{s}$ & Ice-covered ocean north of $49^{\circ} \mathrm{N}$ \\
\hline SST & Sea surface temperature & $\mathrm{K}$ & Ocean north of $60^{\circ} \mathrm{N}$ \\
\hline $\mathrm{T} 2 \mathrm{~m}$ & Surface air temperature at $2 \mathrm{~m}$ & $\mathrm{~K}$ & Ocean north of $60^{\circ} \mathrm{N}$ \\
\hline DLWF & Downward surface longwave radiation flux & $\mathrm{W} / \mathrm{m}^{2}$ & Ocean north of $60^{\circ} \mathrm{N}$ \\
\hline DSWF & Downward surface shortwave radiation flux & $\mathrm{W} / \mathrm{m}^{2}$ & Ocean north of $60^{\circ} \mathrm{N}$ \\
\hline NLWF & Net surface longwave radiation flux & $\mathrm{W} / \mathrm{m}^{2}$ & Ocean north of $60^{\circ} \mathrm{N}$ \\
\hline NSWF & Net surface shortwave radiation flux & $\mathrm{W} / \mathrm{m}^{2}$ & Ocean north of $60^{\circ} \mathrm{N}$ \\
\hline Tadv & Meridional temperature advection & $\mathrm{K} / \mathrm{s}$ & North of $60^{\circ} \mathrm{N}$ \\
\hline SLP & Sea-level pressure & $\mathrm{hPa}$ & North Hemisphere \\
\hline $\mathrm{U} 10 \mathrm{~m}$ & Zonal component of wind at $10 \mathrm{~m}$ & $\mathrm{~m} / \mathrm{s}$ & North Hemisphere \\
\hline $\mathrm{V} 10 \mathrm{~m}$ & Meridional component of wind at $10 \mathrm{~m}$ & $\mathrm{~m} / \mathrm{s}$ & North Hemisphere \\
\hline $\mathrm{AO}^{1}$ & Arctic Oscillation index & & \\
\hline PNA $^{1}$ & Pacific-North American index & & \\
\hline $\mathrm{PDO}^{1}$ & Pacific Decadal Oscillation index & & \\
\hline
\end{tabular}

The previous Arctic SIE was not used as the candidate factor, because this study aimed to validate how the antecedent climate conditions affect the sea-ice cover changes, excluding the strong 
auto-correlated SIE. That is, whenever the previous SIE was considered into the CEN approach, the SIE at a lead of 1 month had a larger effect on September Arctic SIE than any other variables, which to a large degree covered up the real causality. However, the earlier stage of sea ice could also promote or preclude the ice growth and decay, so that some variables indicative of sea ice features remained.

\subsubsection{Sea-Ice Concentration and Extent}

September SIE were from Sea Ice Index data set provided by the NSIDC $[8,39]$. The monthly SIEs (the total area of all the pixels enclosed in the Arctic region with at least a 15\% sea-ice concentration (SIC)) were estimated based on the daily gridded SIC from the Goddard Space Flight Center (GSFC). The SIC maps were derived from multiple passive microwave instruments, including the Nimbus-7 Scanning Multichannel Microwave Radiometer (SMMR, 26 October 1978-20 August 1987), the Defense Meteorological Satellite Program (DMSP) Special Sensor Microwave/Imagers (SSM/Is, 21 August 1987-31 December 2007), and the DMSP Special Sensor Microwave Imager/Sounder (SSMIS, since 2008). They were merged into a consistent time series spanning 1978 through the present by means of the NASA Team sea ice algorithm [40,41]. In detail, the daily SIC fields were firstly used to generate the daily SIE with a $15 \%$ cutoff, which were averaged into the monthly mean extent. The Arctic SIE product included the Arctic pole hole not imaged by the sensors, given that all of grid cells covering the hole had a $15 \%$ or greater ice concentration. We also used the monthly SIC data available from NSIDC to investigate the influence of spatial distribution of sea ice on the changing SIE.

\subsubsection{PIOMAS}

A 12-category thickness and enthalpy distribution (TED) sea-ice model was orchestrated by the Parallel Ocean Program (POP) to develop a PIOMAS which has a north pole displaced to Greenland and an approximately 22-km horizontal resolution [42]. The model, forced by daily NCEP/NCAR reanalysis atmospheric fields, simulates a lot of key sea-ice and ocean states from 1978 to the present, including SIC and sea-ice thickness. The sea-ice volume can then be computed from these two variables. PIOMAS also generated ocean salinity, temperature and velocity at all 10 upper levels which compensated for sparse ocean observations, although they had more or less some biases. Besides the pan-Arctic sea-ice volume, other gridded sea-ice variables from PIOMAS were also considered as candidate factors, such as monthly sea-ice thickness and sea-ice velocity (zonal and meridional components). Note that the sea-ice velocity from the east or north direction was positive.

\subsubsection{Interim European Centre for Medium-Range Weather Forecasts (ECWMF) Re-Analysis (ERA-Interim)}

To explore the impact of changes in atmosphere and ocean states on the SIE, we used the output from the ERA-Interim reanalysis data provided by the European Center for Medium-Range Weather Forecasts (ECMWF) [43,44]. Compared with prior ECMWF reanalysis product (ERA-15 and ERA-40), the updated data mapped on an 80-km, Equal-Area Scalable Earth (EASE) grid implements four-dimensional variational (4D-Var) data assimilation, which adjusts the observation biases and enhances diagnostic efficiency [45,46]. ERA-Interim reanalysis data spans the period from 1979 onwards. Here, we primarily focused on the monthly surface fields, including SST, air temperature at 2-m height, downward surface longwave and shortwave radiation fluxes, net longwave and shortwave radiation fluxes on the surface, sea-level pressure, and zonal and meridional components of wind at $10-\mathrm{m}$ height. The meridional temperature advection was also inferred as the product of meridional wind and latitudinal temperature gradient. It should be noted that the southerly wind (poleward) was positive and the direction of radiation flux followed the convention that downwards was positive.

\subsubsection{Climate Indices}

Three climate teleconnection indices were considered in this study. They are AO index, PNA, and PDO. The first two were provided by the National Weather Service Climate Prediction Center (CPC), 
while the last one was obtained from the Climate Impacts Group at University of Washington. All of these monthly indices were constructed by regressing monthly climate anomaly fields poleward of $20^{\circ} \mathrm{N}$ onto their corresponding leading EOF modes, and then normalized by the standard deviation during their base period.

\subsection{Methodology}

Firstly, we computed the correlation coefficients between September Arctic SIE and each gridded variable at each point for different lead times (1 to 8 months) and constructed the correlation maps for each of the variables (Figures S1-S8, Supplementary Materials). The reason for setting the lead time between 1 and 8 months is because our study aimed at the intra-seasonal and seasonal impacts of climate variables in the same year on the September sea-ice changes. In some cases, only physically valid points were considered. For example, warmer SST is favorable for sea-ice loss, so the correlations between the two were presumably negative. It is therefore areas with positive correlations between the September SIE and August SST anomalies were set to 0 [47]. Based on a two-sided Student's $t$-test analysis, the statistically significant adjacent grids with the same sign at a $95 \%$ confidence level were grouped into the same region, where the weighted regional mean time series at a specific lead time were generated with corresponding correlation weights [47-49]. This step reduced the dimension of these potential impact factors efficiently but still preserved the correlation information and similar properties in this region.

Based on the correlation-weighted time series of each variable constructed in the first step, we detected the direct precursors related to the SIE at different lead times using the CEN algorithm $[50,51]$. This data-driven method has been increasingly utilized in climate research fields [52-54]. Generally, the updated version of PC algorithm (a causal discovery algorithm developed by Peter Spirtes and Clark Glymour) [55,56] sheds light on the direct links between an independent variable and a dependent variable with conditional independence tests given more than two variables. Its usage was described in details by Kretschmer et al. [57]. In our study, this step mainly includes two parts. The first one is to calculate the simple linear correlations between September Arctic SIE and weighted regional mean factors selected from the first step, and to retain significantly correlative potential precursors. The second and critical one is to iteratively compute partial correlation coefficients between the September Arctic SIE and one tested potential precursor given some independent conditions. These conditions actually are different combinations of other potential precursors, except for the tested precursor. Once the partial correlation between the September SIE and the tested potential precursor is nonsignificant under any condition, the tested potential precursor is viewed as an indirect link and removed. Finally, we retained all of causal precursors at a specific lead time after removing non-significant or indirect links at a confidence level (95\%). These causal precursors were used to build a multiple linear regression model.

In order to validate the robustness of the regression model, we chose the first 30-year data (1980-2009) to construct a cross-validated training model with these selected CEN precursors, which were used to predict the September Arctic SIE during the last 8 years (2010-2017). Note that all of variables over the whole 38 years were re-processed based on the long-term means and linear trends of the training data over 1980-2009.

\section{Results}

From the lagged correlation maps, we obtained a total of 7151 regions significantly correlated with the September Arctic SIE for all gridded variables for all lead times (1-8 months), including 3509 SIC regions, 256 SIT regions, 649 Uice regions, 675 Vice regions, 139 SST regions, 87 T2m regions, 140 DLWF regions, 27 DSWF regions, 57 NLWF regions, 69 NSWF regions, 409 Tadv regions, 93 SLP regions, $547 \mathrm{U} 10 \mathrm{~m}$, and $494 \mathrm{~V} 10 \mathrm{~m}$ regions. Based on the CEN method, we found some direct precursors in specific regions at specific lead times, which represent the factors significantly correlated with the September Arctic SIE. For example, sic_27 and sic_121 are the August regional mean SICs in the 27th 
and 121st group of 3509 SIC regions, respectively, while $d l w f \_84$ is the June regional mean downward longwave radiation flux in the 84th group of 140 DLWF regions (Figure 1).
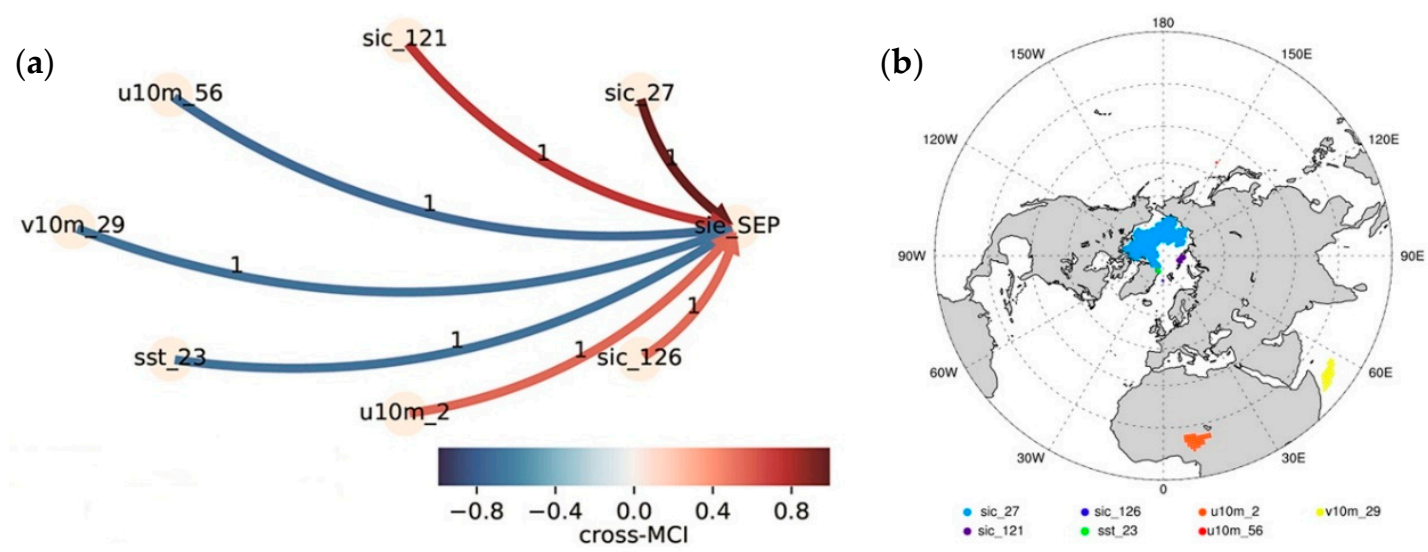

Figure 1. (a) Causal effect networks (CEN) process graph between precursors and the September Arctic SIE when the lead time maximum is less than four months. The line color means negative (blue) or positive (red) correlation. The number on the line means the lead time of each precursor; (b) Spatial distribution of precursors of the September Arctic SIE. Node colors correspond to different precursors. The number after the underline in the legend represents the group each variable belongs to. For example, "sic_27" means the 27th group in 3509 regions of SICs associated with September Arctic SIEs for all lead times (1-8 months).

Concerning the parameter setting of the CEN method, we tried to adjust the maximal lead time from one to eight months relative to September in the same year. Finally, all of regional mean precursors for different lead times are listed in Table 2, along with their geometric center coordinates and correlation coefficients corresponding to Figure 1a. Two kinds of distinct links were found. The first with only one precursor, June DLWF in the area of Canadian Arctic Archipelago dlwf_84 (centered on $69.0^{\circ} \mathrm{N}, 89.3^{\circ} \mathrm{W}$; hereinafter, the geometric center coordinates of each precursor follow in the parentheses), occurs when the maximum lead time is more than three months, while the other has seven significant precursors in August connected with the September SIE when the lead time maximum is less than four months (Figure 1a). These precursors are arranged counterclockwise in order of correlation strength, with the mean SIC in Western Arctic sic_27 $\left(81.0^{\circ} \mathrm{N}, 156.8^{\circ} \mathrm{W}\right)$ being the largest $(r=0.972)$. Besides the SIC factors, both wind fields and SST are correlated with the changes in SIE. As is shown in Figure 1a, the correlation coefficients between the first five strongest precursors and September Arctic SIE exceed 0.7. Although some precursors are from the same variable, they are located in different regions (Figure $1 \mathrm{~b})$. In terms of the SIC, other than sic_27 $\left(81.0^{\circ} \mathrm{N}, 156.8^{\circ} \mathrm{W}\right)$ mentioned above, the negative anomalies of ice concentration in the north of Kara Sea sic_121 $\left(81.0^{\circ} \mathrm{N}\right.$, $\left.79.8^{\circ} \mathrm{E}\right)$ could result in the less SIE, while the sea-ice concentrations between the Greenland and Svalbard sic_126 $\left(77.4^{\circ} \mathrm{N}, 1.1^{\circ} \mathrm{W}\right)$ have the weakest positive correlation with the September SIE $(r=0.55)$, which is close to the effect of the zonal wind anomalies in the north of Africa $u 10 m \_2$ $\left(10.3^{\circ} \mathrm{N}, 9.9^{\circ} \mathrm{E}\right)$. From Figure 1, we can see the August zonal wind in the Pacific Ocean adjacent to the east of Japan $u 10 m \_56\left(39.0^{\circ} \mathrm{N}, 150.8^{\circ} \mathrm{E}\right)$, meridional wind in the Indian Ocean to the east of Somalia $v 10 m \_29\left(6.3^{\circ} \mathrm{N}, 53.7^{\circ} \mathrm{E}\right)$ and SST near Northeastern Greenland $s s t \_23\left(81.9^{\circ} \mathrm{N}, 18.2^{\circ} \mathrm{W}\right)$ more or less negatively correlate with the subsequent Arctic SIE change. However, all of climate indexes were not selected in any case, which indicates they affect Arctic sea ice on longer time scales rather than on a seasonal time scale. Moreover, zonal and meridional sea-ice velocity have never appeared for all lead time, which may be linked with the lack of real ice velocity observations assimilated in the PIOMAS model and the complexity of sea ice rheology. 
Table 2. Precursors associated with September Arctic SIE.

\begin{tabular}{|c|c|c|c|c|}
\hline Name & $\begin{array}{l}\text { Lead } \\
\text { Time }\end{array}$ & Description & $\begin{array}{c}\text { Center } \\
\text { Coordinates }\end{array}$ & Correlation \\
\hline sic_27 & 1 & August regional mean SIC in the 27th group of 3509 SIC regions & $81.0^{\circ} \mathrm{N}, 156.8^{\circ} \mathrm{W}$ & 0.972 \\
\hline sic_121 & 1 & August regional mean SIC in the 121st group of 3509 SIC regions & $81.0^{\circ} \mathrm{N}, 79.8^{\circ} \mathrm{E}$ & 0.736 \\
\hline$u 10 m \_56$ & 1 & $\begin{array}{l}\text { August regional mean zonal wind at } 10 \mathrm{~m} \\
\text { in the 56th group of } 547 \mathrm{U} 10 \mathrm{~m} \text { regions }\end{array}$ & $39.0^{\circ} \mathrm{N}, 150.8^{\circ} \mathrm{E}$ & -0.725 \\
\hline$v 10 m \_29$ & 1 & $\begin{array}{l}\text { August regional mean meridional wind at } 10 \mathrm{~m} \\
\text { in the } 29 \text { th group of } 494 \mathrm{~V} 10 \mathrm{~m} \text { regions }\end{array}$ & $6.3^{\circ} \mathrm{N}, 53.7^{\circ} \mathrm{E}$ & -0.684 \\
\hline sst_23 & 1 & August regional mean SST in the 23th group of 139 SST regions & $81.9^{\circ} \mathrm{N}, 18.2^{\circ} \mathrm{W}$ & -0.681 \\
\hline$u 10 m \_2$ & 1 & $\begin{array}{l}\text { August regional mean zonal wind at } 10 \mathrm{~m} \\
\text { in the 2nd group of } 547 \mathrm{U} 10 \mathrm{~m} \text { regions }\end{array}$ & $10.3^{\circ} \mathrm{N}, 9.9^{\circ} \mathrm{E}$ & 0.558 \\
\hline sic_126 & 1 & August regional mean SIC in the 126th group of 3509 SIC regions & $77.4^{\circ} \mathrm{N}, 1.1^{\circ} \mathrm{W}$ & 0.553 \\
\hline$d l w f \_84$ & 3 & $\begin{array}{l}\text { June regional mean downward longwave radiation flux } \\
\text { in the 84th group of } 140 \text { DLWF regions }\end{array}$ & $69.0^{\circ} \mathrm{N}, 89.3^{\circ} \mathrm{W}$ & -0.950 \\
\hline
\end{tabular}

The bold-italic style means the specific terminology in this article.

The bold-italic style means the specific terminology in this article According to these precursors above, the regression model of September Arctic SIE for the lead time of 1-3 months was:

$$
Y=0.72 X_{1}^{-1}+0.2 X_{2}^{-1}-0.19 X_{3}^{-1}-0.17 X_{4}^{-1}-0.17 X_{5}^{-1}+0.13 X_{6}^{-1}+0.12 X_{7}^{-1}
$$

where data are standardized, $Y$ represents the September Arctic SIE, and $X_{i}^{-j}$ denotes the specific precursor at lead $j$ month corresponding to these seven significant precursors in August from sic_27 to $s i c_{-} \mathbf{1 2 6}$ in counterclockwise order, shown in Figure 1a. The skill of model is strong because the simulated September SIE is highly correlated with observations $(r=0.986)$. Furthermore, based on the cross-validation model over 1980-2009, there is a high correlation $(r=0.979)$ between predicted and observed September SIEs during the testing period (Figure 2), which indicates the seven precursors shown in Figure 1a can be used to predict the September Arctic SIE in the following years very well.

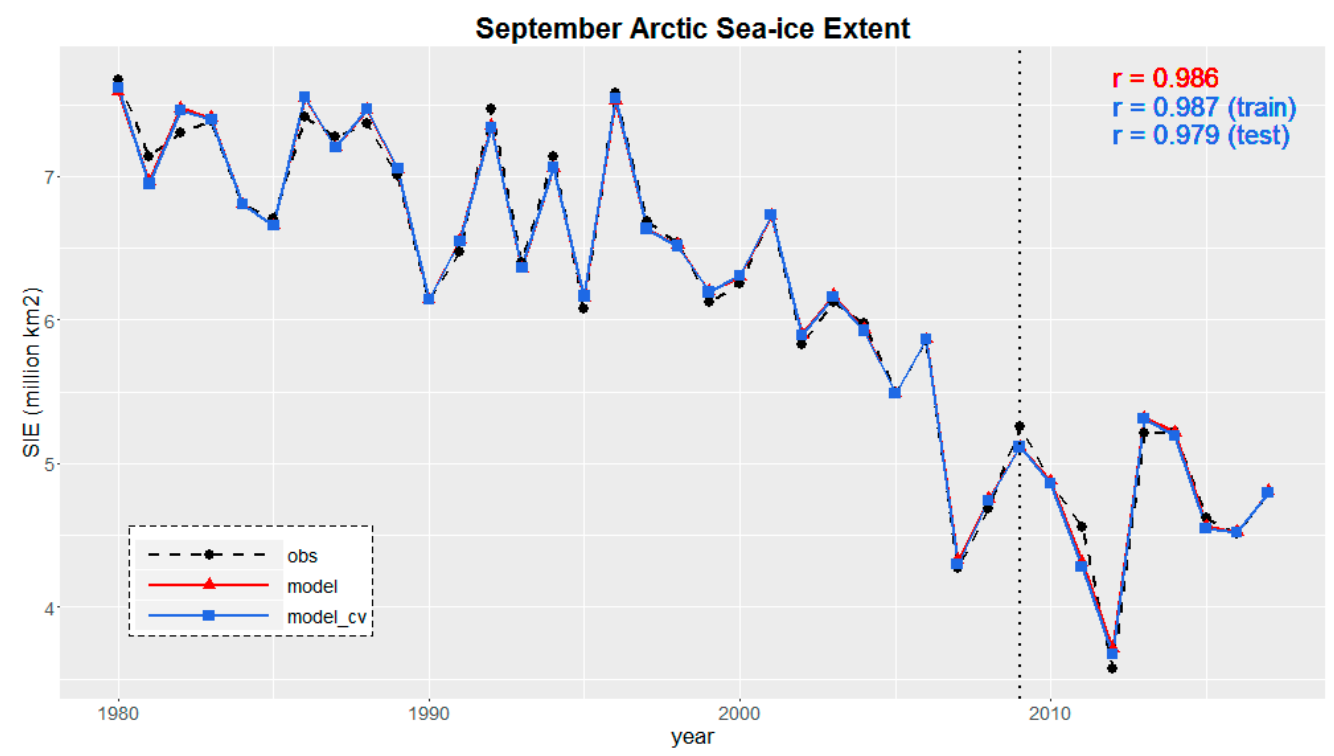

Figure 2. Observed (black dashed line) and simulated September Arctic SIE over 1980-2017. Red solid line represents the linear regression model of September SIE using the whole data, while the blue one represents the crossed-validation model of September SIE using 1980-2009 training data. The blue one almost overlaps with the red one totally. The left of vertical dotted line means the fitted training results (1980-2009) based on the crossed-validation model, while the right of vertical dotted line means the predicted results during the testing period (2010-2017). 
As the causal effect network algorithm is essentially a statistical approach, it is of importance to explain how some selected precursors with only few points, even in the lower latitudes, relate to the Arctic SIE anomalies. As we know, the previous SIC changes largely concur with the subsequent SIE anomaly due to the persistence, which is corroborated by the cross-correlations between the detrended September Arctic SIE and August SIC anomaly field during the study period (Figure 3a). The SIE in September are positively correlated with the ice concentrations in most of the pan-Arctic regions in August, except for the part of the central Arctic Basin which can be ignored. All of these significantly correlative points were divided into 137 groups where the adjacent grids with the same sign were enclosed in the same group. The three precursors, sic_27, sic_121, and sic_126, indicate the regional averages of the 27th, 121st and 126th group, respectively, in the SIC precursor regions related to the September Arctic SIE. For exploring the role of each precursor, we chose the geometric mid-point of each group as a base grid to construct its corresponding one-point correlation maps [58] where the points positively correlated $(p<0.05)$ with base grid were considered to be in accordance with the precursor (Figure $3 \mathrm{~b}-\mathrm{d}$ ). What is interesting is that the significantly positive points in these three one-point correlation maps add up to the whole positive correlation region in Figure 3a. Moreover, the more the positive points in a one-point correlation map are, the stronger the correlation of the relevant precursor with September SIE is. Therefore, it is likely that the dramatic loss of September SIE is accentuated by negative August SIC anomalies in the Beaufort Sea and the Arctic Basin extending to the Canadian Arctic Archipelago (sic_27), where sea ice is susceptible to the change in the strength and location of Beaufort Gyre and the heat flux once the thicker ice shrinks. Moreover, there is no doubt that the continued negative SIC anomalies in the Kara Sea and Laptev Sea will result in the subsequent sea-ice reduction, because SIE was derived from the ice-covered areas with SIC greater than $15 \%$. According to the CEN method, the results showed that, except for SICs, other variables associated with sea-ice characters were not selected, which indicated the sea-ice thickness to a large degree affects SIE through the changes in ice concentrations.

Although the sea-ice feature itself plays a vital role, it does not impede the influence of SST on the sea-ice cover. The warm sea water at the surface accelerates the melting of sea ice and the decrease of surface albedo, which makes the open water areas enlarge so that more heat is absorbed in the surface and subsurface ocean. The positive temperature-albedo feedback has a fundamental effect on the sea-ice changes. From Figure 1b, we can see that the August sst_23 indicative of some sparse grid points near Northeastern Greenland has a remarkably negative impact on the September SIE. Compared to the negative SST anomalies in other larger regions easily caused by atmosphere circulation anomaly and warm water inflow from lower latitudes, sst_23, a local variable, could directly affect sea-ice changes. Figure 4 shows the composite patterns of August SST anomaly (left) and September SIC anomaly (right). When the regional mean sst_23 in August is one standard deviation larger than its climatology mean in the positive phase, the warmer SST anomalies occur in the vicinity of Barents Sea and Kara Sea and along the Eurasian coast (Figure 4a). However, there is a little change in SICs near the extremely warm Barents Sea and Kara Sea (Figure 4b). In contrast, the SICs within the Arctic Basin to the north of Barents Sea and Kara Sea significantly decrease, because in summer, sea-ice cover shrinks to the north of $75^{\circ} \mathrm{N}$, where sea ice mostly locates in the Central Arctic. Similar to extreme warmer sst_23 anomaly years, more ice in the Laptev Sea disappears in cooler years (Figure 4d), which reveals the sea-ice changes in this region is less correlated with SST anomalies near Northeastern Greenland. 

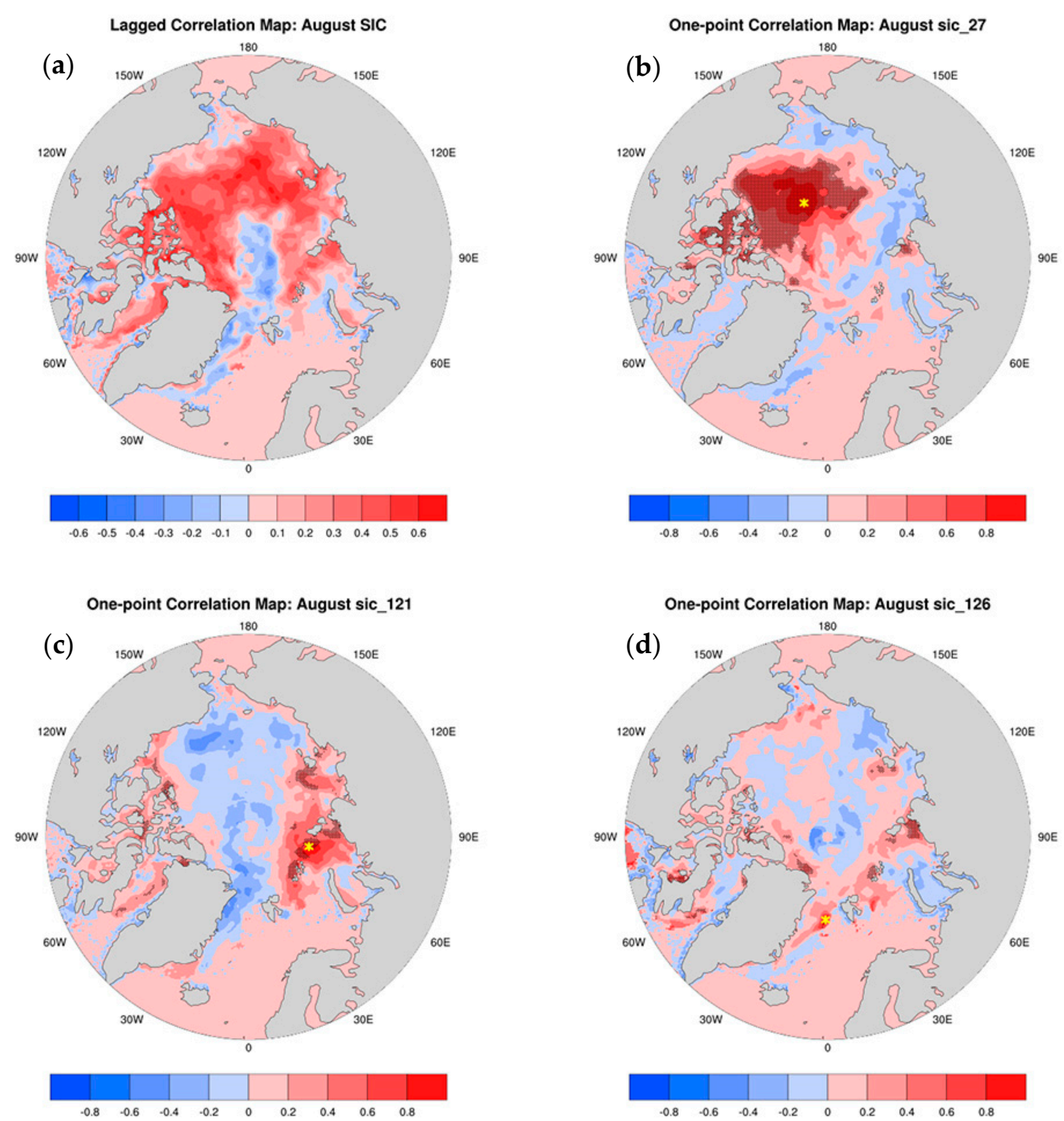

Figure 3. (a) Correlation map (shade interval: 0.1) of August SIC with the September Arctic SIE over 1980-2017; (b-d) one-point correlation maps (shade interval: 0.2) of three precursors (August sic_27, sic_121 and sic_126) where the values represent the correlation coefficients of each precursor with the August SIC anomaly field north of $60^{\circ} \mathrm{N}$, respectively. The geometric mid-point (base grid) of each precursor is marked as a yellow asterisk. Black dots denote the points significantly correlated with each base grid at the $95 \%(p<0.05)$ confidence level. Red (blue) shadings indicate the positive (negative) correlations.

Besides SST, the anomalous preconditioning of atmosphere circulation on the hemispheric scale is likely to cause the sea-ice loss. As is shown in Figure 5, the August westerly wind anomaly in the Pacific Ocean adjacent to the east of Japan $\left(\mathbf{u 1 0 m \_ 5 6 )}\right.$ is accompanied by the strong easterly wind anomalies in the Chukchi Sea. In the extreme positive $\boldsymbol{u 1 0 m} \mathbf{5 6}$ years, the circulation configuration helps the warm air poleward through the Bering Strait and makes the sea ice away from the Eurasian coast driven by the Transpolar Drift Stream (high ice motion from the coast of Siberia, across the Arctic pole into the North Atlantic via the Fram Strait), while the more sea ice can only be preserved in the Beaufort Sea (Figure $5 b$ ). In contrast, the extreme negative $\boldsymbol{u 1 0} \_\mathbf{5 6}$ phase with low pressure anomaly in the central Arctic Ocean weakens the Beaufort Gyre in a smaller size, which makes thinner ice recirculate back to the Alaskan coast more quickly, and the Transpolar Drift Stream is enhanced, shifting to the western Arctic, and takes more older ice in the central Arctic Basin away through the Fram Strait (Figure 5c,d). 
These results are similar to [24], which demonstrated the summer sea-ice motion (SIM) anomalies from the 1980s to the 1990s are the delayed responses to the AO of the previous winter.
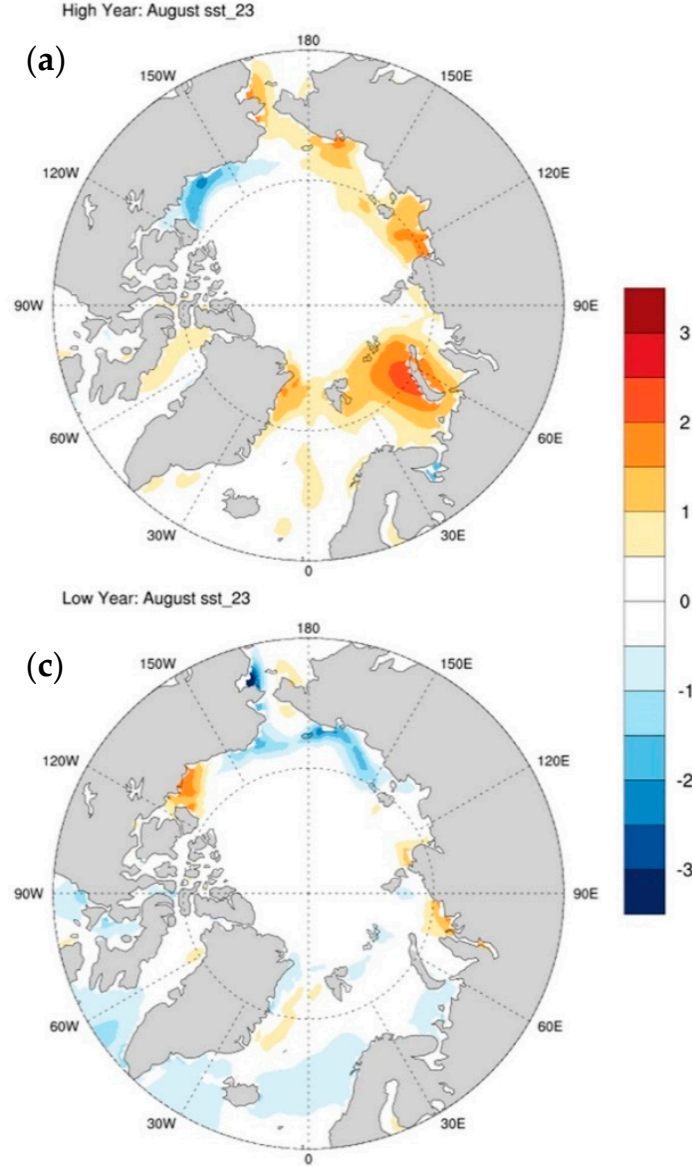

High Year: August sst_23
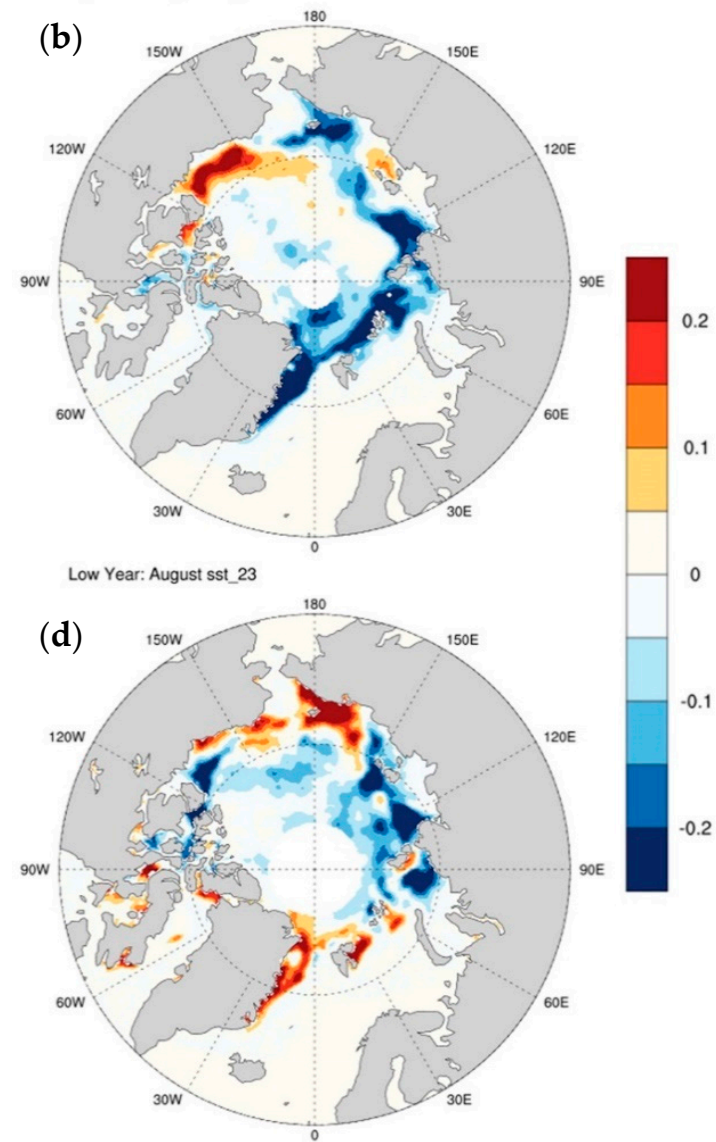

Figure 4. Composite anomalies of (a,c) August SST (shade interval: $0.5 \mathrm{~K}$ ) and (b,d) September SIC (shade interval: 0.05). The top (bottom) two plots correspond to the years when August sst_23 $\left(81.9^{\circ} \mathrm{N}\right.$, $18.2^{\circ} \mathrm{W}$ ) is one standard deviation larger than its climatology mean in the positive (negative) phase.

Similarly, with the abnormal southerly wind near the West Indian Ocean (v10m_29), the Laptev Sea towards the Central Arctic witnesses a dramatically positive meridional wind anomaly, which leads to a low-pressure center in the vicinity of the Laptev Sea and Kara Sea and a high-pressure center in the western Arctic Basin (Figure 6a,b). Therefore, the warm air from lower latitudes is transported into the Arctic regions to melt a mass of ice with the largest loss in the Laptev Sea. Meanwhile, the Transpolar Drift Stream is shifted eastwards by the stronger Beaufort Gyre so as to make more fast ice out of the marginal seas in Eastern Arctic. 


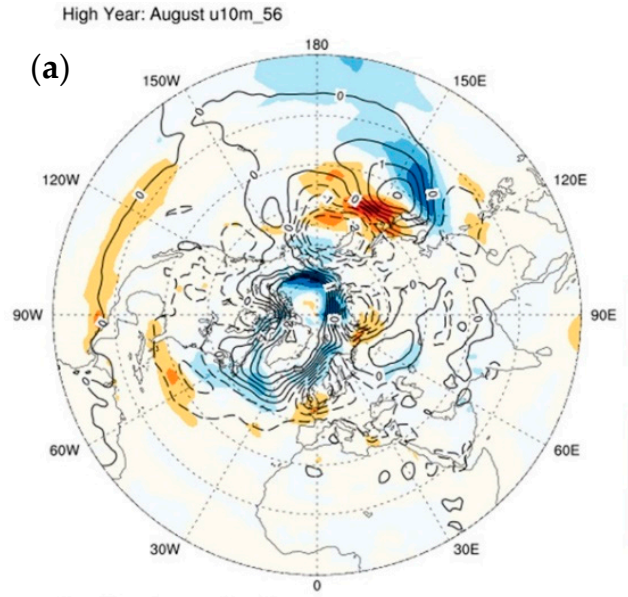

Low Year: August u10m_56

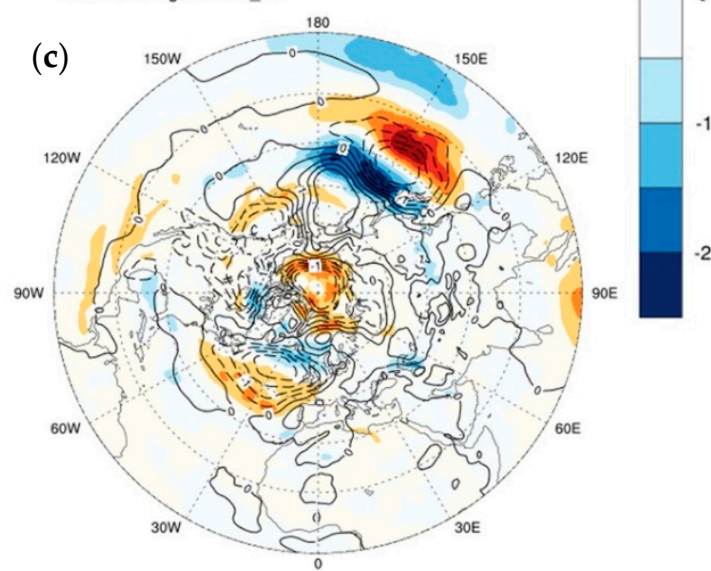

High Year: August u10m_56

(b)
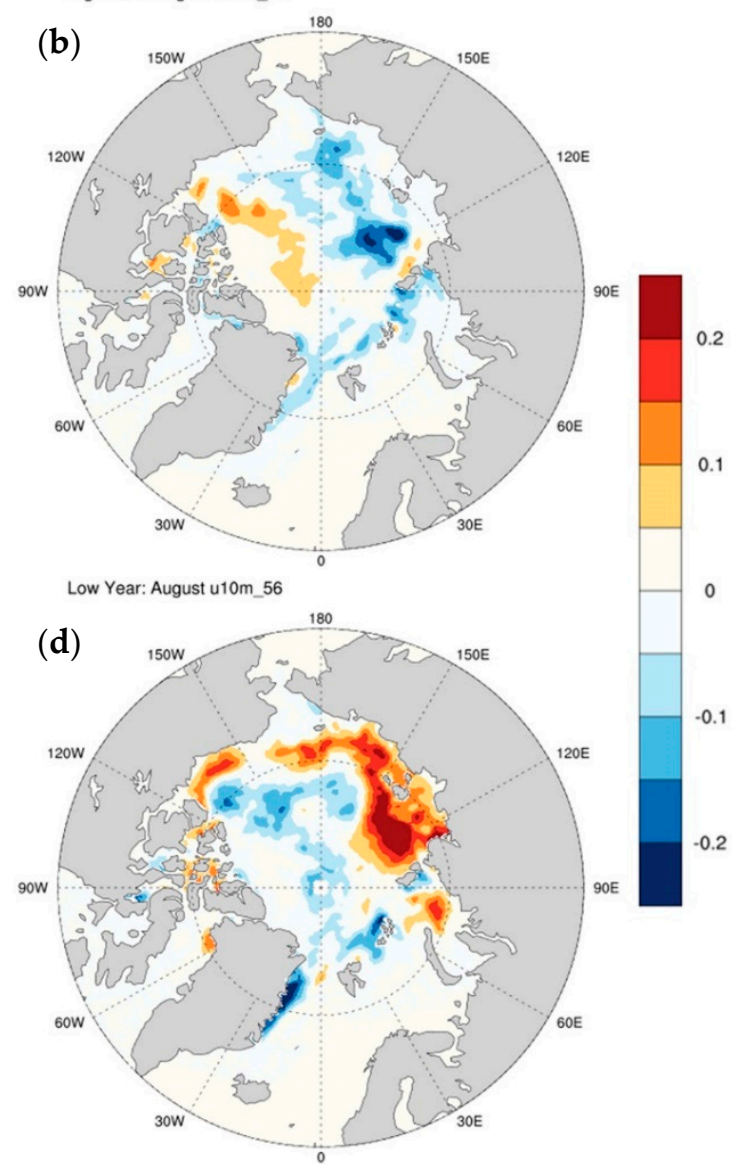

Figure 5. Composite anomalies of $(\mathbf{a}, \mathbf{c})$ August zonal component of wind at $10 \mathrm{~m}$ (shade interval: $0.5 \mathrm{~m} / \mathrm{s}$ ) and sea-level pressure (contour interval: $0.5 \mathrm{hPa}$ ); and (b,d) September SIC (shade interval: 0.05). The top (bottom) two plots correspond to the years when August $u 10 m \_56\left(39.0^{\circ} \mathrm{N}, 150.8^{\circ} \mathrm{E}\right)$ is one standard deviation larger than its climatology mean in the positive (negative) phase.

However, the surface wind anomalies in different regions have different even adverse influences on sea ice. As is shown in Figure 1, the August zonal winds in the north of Africa $\left(u 10 m \_2\right)$ have a weak positive correlation with the September Arctic SIE, unlike $u 10 m \_56$ and $v 10 m \_29$. Figure 7 reveals that in the extreme negative $\mathbf{u 1 0} \_\mathbf{2}$ anomaly years, the abnormal westerly winds occur across the tropical Pacific Ocean and Indian Ocean accompanied with the large-scale easterly wind anomaly near the north latitude $30^{\circ}$, which indicates the westerly zone in the mid-latitudes weakens and the heat exchange between higher and lower latitudes is enhanced, so the Arctic sea ice, especially in the Pacific side, is reduced. In contrast, in the extreme positive $\mathbf{u 1 0} \_\mathbf{2}$ phase, both the stronger westerly zone and the polar vortex confine the cold air in the Arctic regions in favor of ice growth. 

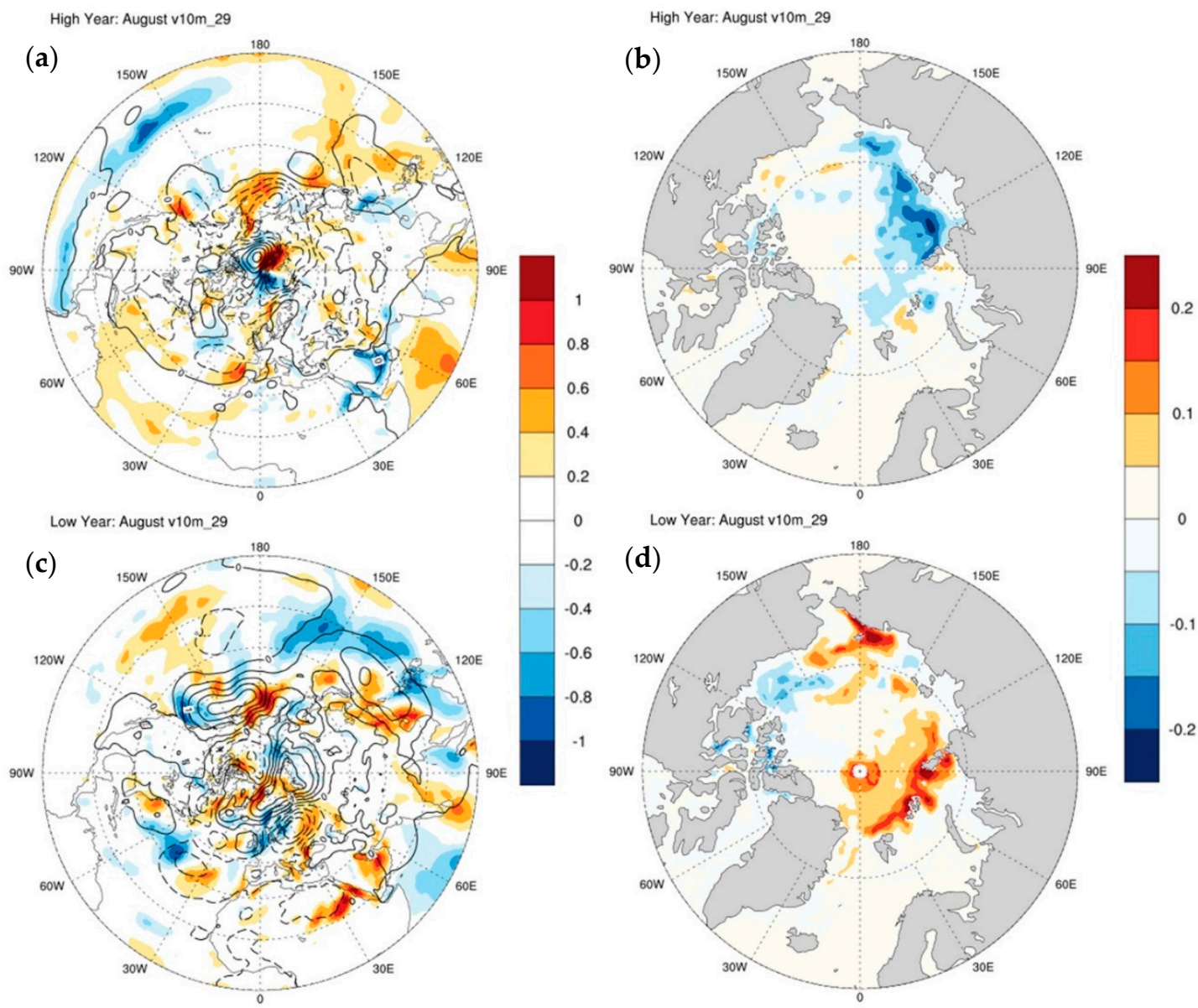

Figure 6. Composite anomalies of (a,c) August meridional component of wind at $10 \mathrm{~m}$ (shade interval: $0.2 \mathrm{~m} / \mathrm{s}$ ) and sea-level pressure (contour interval: $0.5 \mathrm{hPa}$ ); and $(\mathbf{b}, \mathbf{d})$ September SIC (shade interval: 0.05). The top (bottom) two plots correspond to the years when August $v 10 m \_29\left(6.3^{\circ} \mathrm{N}, 53.7^{\circ} \mathrm{E}\right)$ is one standard deviation larger than its climatology mean in the positive (negative) phase.

Different from the diverse factors above, the June DLWF in the vicinity of Canadian Arctic Archipelago (dlwf_84) is the only one relevant precursor when the lead time maximum is more than three months in the CEN algorithm. Additionally, the results revealed that the effect of June $d l w f \_84$ on September Arctic SIE is profound. Comparing the composite patterns in the extreme positive and negative $d l w f \_84$ anomaly years (Figure 8a,c), we found a wide range of DLF anomalies in the central Arctic Basin extending to the Eurasian coast, the Baffin Bay and the Hudson Bay in June are concurrent with the abnormal $d l w f \_84$. In other words, when $d l w f \_84$ is one standard deviation larger than its climatology mean in the positive phase, DLFs in the majority of Arctic regions are enhanced, which may result from the increased high clouds and moisture in the high latitudes during the late spring and early summer. Meanwhile, the stronger downward longwave radiation leads to the surface ice melting (Figure 8b) and the albedo decrease with more heat absorbed in the surface ocean, which in turn contributes to the positive ice-albedo feedback and/or cloud-radiation feedback. 

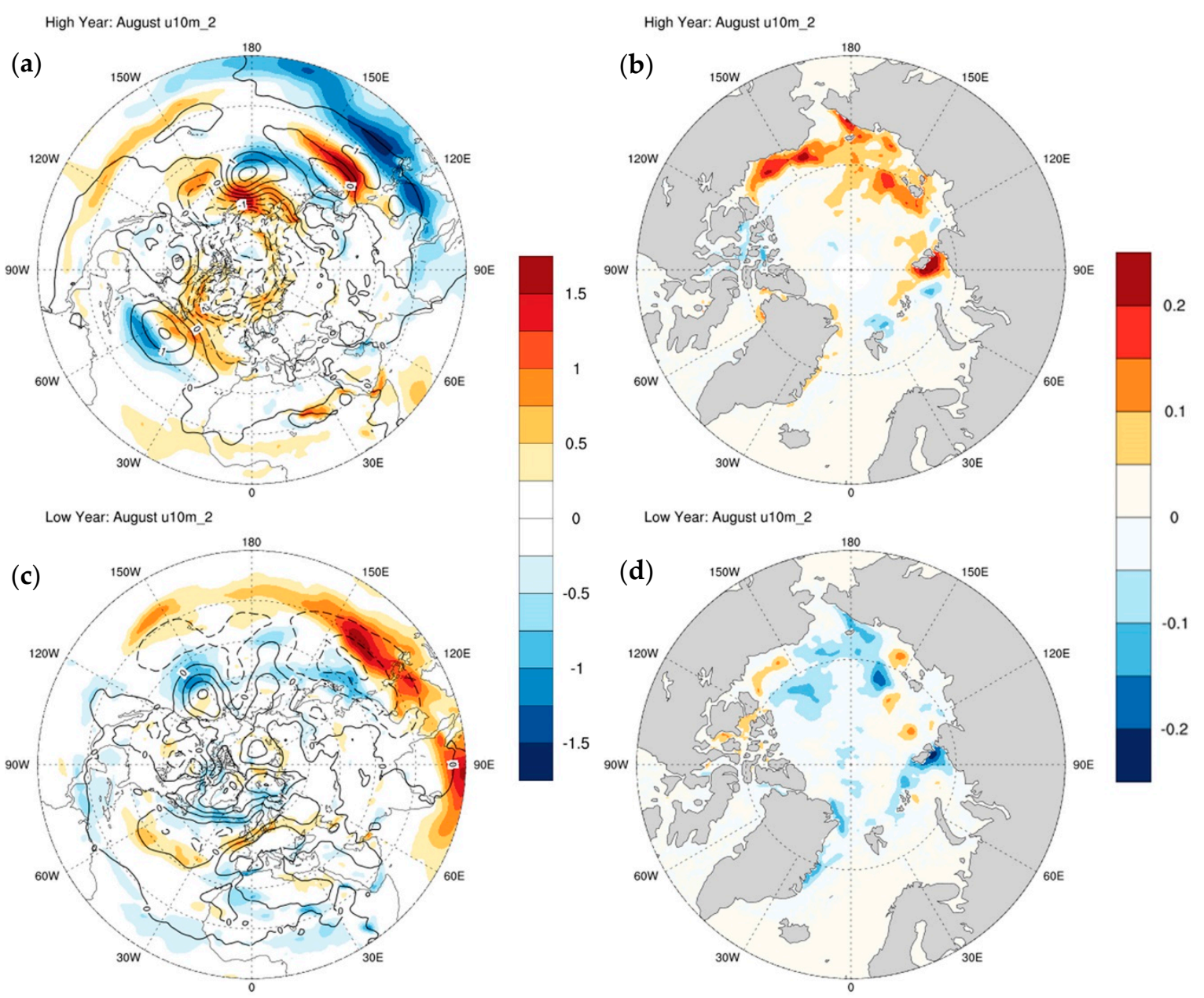

Figure 7. Composite anomalies of (a,c) August zonal component of wind at $10 \mathrm{~m}$ (shade interval: $0.25 \mathrm{~m} / \mathrm{s}$ ) and sea-level pressure (contour interval: $0.5 \mathrm{hPa}$ ); and (b,d) September SIC (shade interval: 0.05). The top (bottom) two plots correspond to the years when August $u 10 m \_2\left(10.3^{\circ} \mathrm{N}, 9.9^{\circ} \mathrm{E}\right)$ is one standard deviation larger than its climatology mean in the positive (negative) phase. 


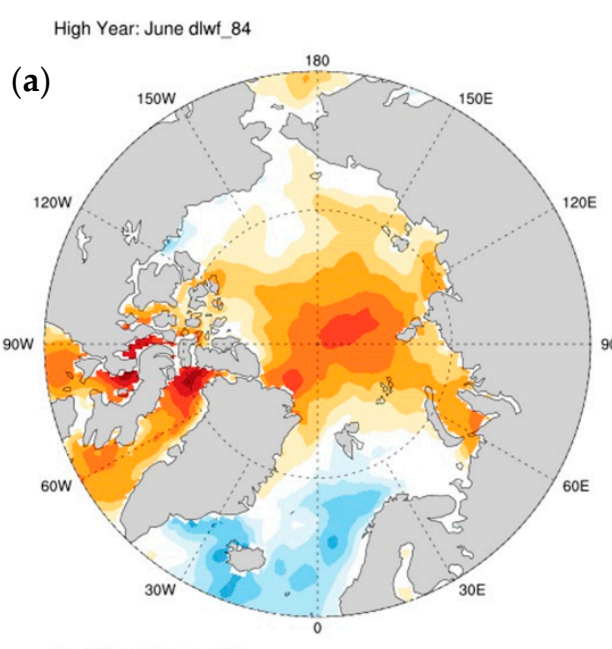

Low Year: June diwf 84

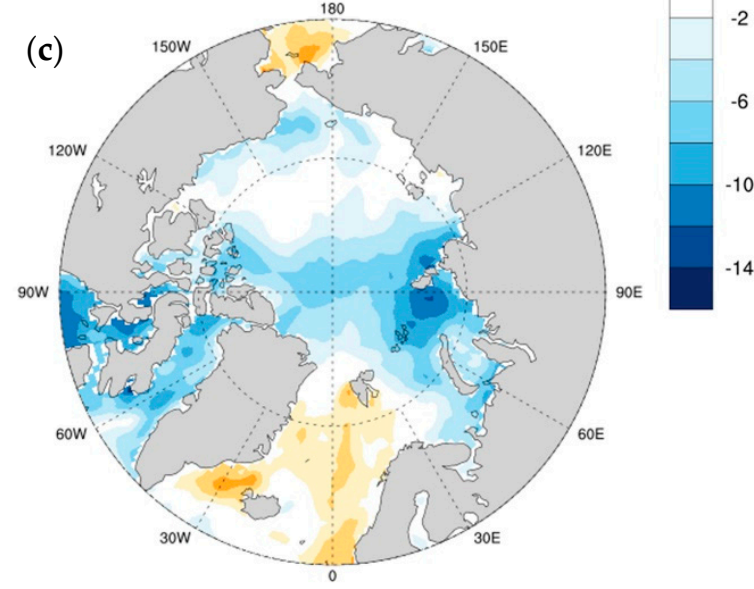

High Year: June dlwt_ 84

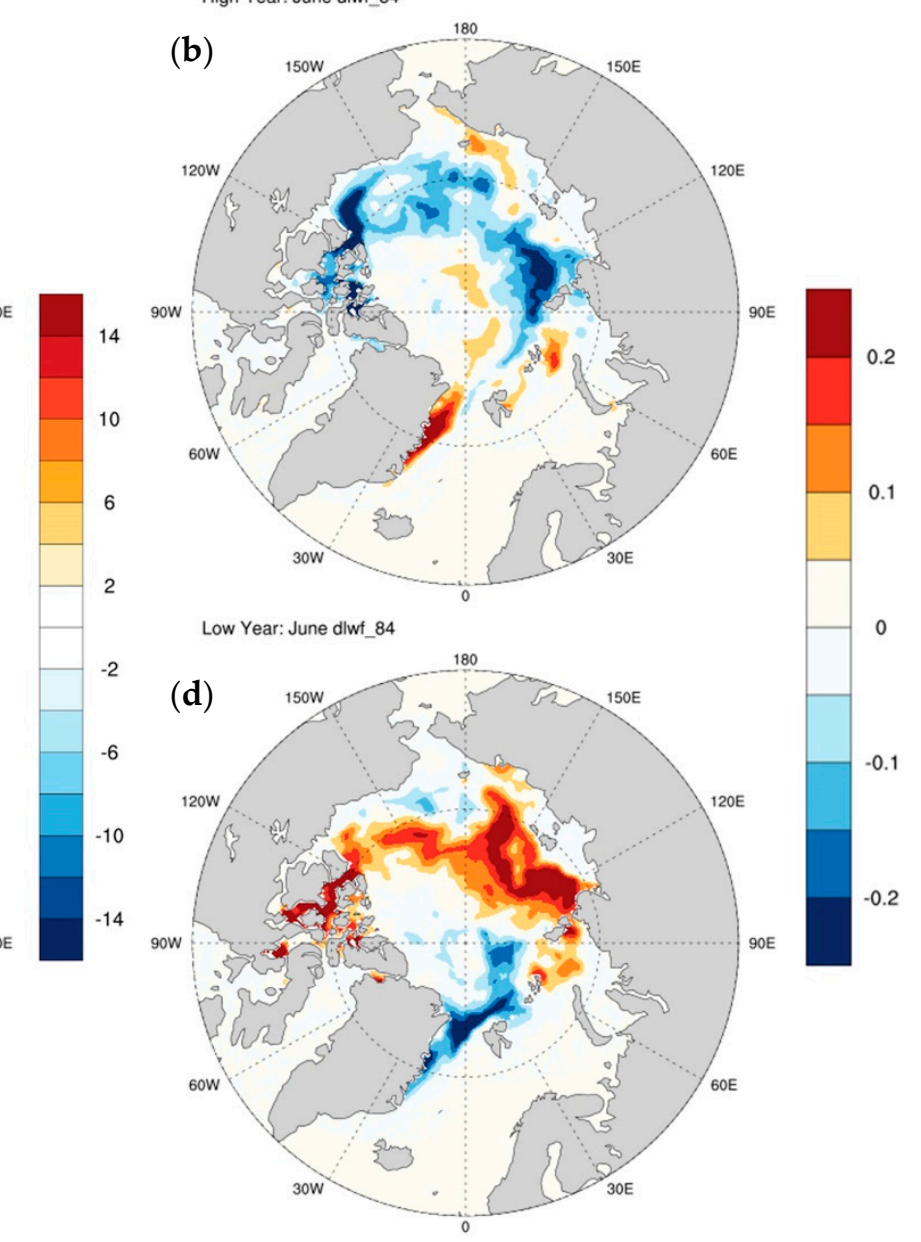

Figure 8. Composite anomalies of (a,c) June DLWF (contour interval: $2 \mathrm{~W} / \mathrm{m}^{2}$ ) and (b,d) September SIC (contour interval: 0.05). The top (bottom) two plots correspond to the years when June $d l w f \_84\left(69.0^{\circ} \mathrm{N}, 89.3^{\circ} \mathrm{W}\right)$ is one standard deviation larger than its climatology mean in the positive (negative) phase. 


\section{Discussion and Conclusions}

Our research illustrates that some climate variables are good predictors as they are directly related to the changes in the September Arctic SIE, which is in agreement with the previous studies $[9,17,19]$. For the lead time of 1-3 months, variables such as SIC, manifesting the characters of sea ice, have a predominate impact. The SIC precursors in three different regions almost delineate the total and close connections between the August SIC and September SIE. sic_27 in the Beaufort Sea and most of the Arctic Basin represents the strongest positive correlation, while the other two precursors, sic_121 and sic_126, have a relatively weaker influence on the changes of marginal seas. Similar to SIC, the sea-ice thickness in the pan-Arctic regions at different lead times highly correlates with September Arctic SIEs (Figure S2, Supplementary Materials). As mentioned above, August SICs in three different regions are important causal precursors of September Arctic SIE, so likewise, the regional mean sea-ice thickness can be considered as predictors of September Arctic SIE [49,59-61]. However, the earlier sea-ice thickness has not been selected through the CEN method. It is likely because in most cases, the thin sea-ice cover is helpful for the subsequent sea-ice loss with the abnormal atmosphere circulations and thermodynamic conditions required, which indicates this kind of indirect correlation is hard to detect through the CEN approach.

Besides sea ice itself, the influences of the previous dynamic and thermodynamic factors, including atmosphere circulation and radiation forcing, are prominent in many regions. As is shown in Figure 4, the September SIC declines near Eastern Greenland and the Arctic Basin to the north of Novaya Zemlya and more or less concurs with local positive SST anomalies near Northeastern Greenland in August (sst_23). Instead, the sea-ice loss in the Laptev Sea, to a large extent, is linked with the August easterly wind anomaly in the Chukchi Sea compatible with the westerly wind anomaly in the Pacific Ocean (u10m_56), so as to enhance the heat exchange between higher and lower latitudes (Figure 5). The analogous circulation regime is found when the meridional wind near the West Indian Ocean (v10m_29) has a positive anomaly, which strengthens the Beaufort Gyre and melts more ice along the Eurasian coast when the Transpolar Drift Stream shifted westward (Figure 6). At the same time, the anomalous polar high favors the clear sky conditions with higher clouds that could accelerate the sea-ice loss through the cloud-radiation feedback. In terms of the radiation forcing, the longwave radiation flux plays a more pronounced role in the September sea-ice changes than shortwave radiation flux, particularly for the lead time of more than three months. Moreover, comparing the correlation maps of the downward DLF and the net longwave radiation flux (NLF) at the surface with the September Arctic SIE (Figures S3 and S4, Supplementary Materials), we considered the former has a dominant influence as well as the June $d l w f_{-} 84$ in the Canadian Arctic Archipelago characterized by the DLF anomalies in the entire Arctic Basin eastwards to the Eurasian coast (Figure 8), and is the only one relevant precursor when the parameter (maximal lead time) in the CEN method is over three months. Based on the spatial distribution of September SIC over 1980-2017 (Figure S9, Supplementary Materials), it is documented that the response of sea ice to the climate precursors is mainly located in the ice edges, which are the most sensitive regions of sea-ice changes.

In this study, we focused on the direct and linear correlations between the potential precursors, and the September Arctic SIE so indirect and/or nonlinear factors were not selected in the CEN method. From our perspectives, the robust and relatively stable precursors not affected by the maximal lead time can be used to build the forecast models. However, to improve the seasonal prediction and predictability of summer Arctic sea ice, more work should be done in the future, including the setting of other parameters (minimal lead time, confidence level, and so on) and the choice of other climate variables. Additionally, the quantitative relationship between these precursors and the September Arctic SIE could provide indicative criteria for the evaluation of climate models so as to address sources of uncertainty and promote the improvement of models.

Supplementary Materials: The following are available online at http:/ / www.mdpi.com/2073-4433/9/11/437/s1, Figure S1: Correlation maps of SIC at the lead time of 1-4 months with the September Arctic SIE, Figure S2: Correlation maps of sea-ice thickness at the lead time of 1-4 months with the September Arctic SIE, Figure S3: 
Correlation maps of downward surface longwave radiation flux at the lead time of 1-4 months with the September Arctic SIE, Figure S4: Correlation maps of net surface longwave radiation flux at the lead time of 1-4 months with the September Arctic SIE, Figure S5: Correlation maps of SST at the lead time of 1-4 months with the September Arctic SIE, Figure S6: Correlation maps of sea-level pressure at the lead time of 1-4 months with the September Arctic SIE, Figure S7: Correlation maps of zonal component of wind at 10-m height at the lead of 1-4 months with the September Arctic SIE, Figure S8: Correlation maps of meridional component of wind at 10-m height at the lead time of 1-4 months with the September Arctic SIE, Figure S9: Climatology mean of September Arctic SIC over 1980-2017.

Author Contributions: Conceptualization, S.L., Y.B., S.X., M.W., J.L., B.W. and Y.W.; methodology, S.L. and M.W.; software, S.L.; validation, S.L., M.W. and N.A.B.; formal analysis, S.L., M.W., N.A.B., W.H. and J.L.; investigation, S.L., S.X., W.H., Y.B., B.W., and Y.W.; resources, M.W. and Y.B.; data curation, S.L.; writing of the original draft preparation, S.L. and Y.W.; writing of review and editing, S.L., M.W., N.A.B., W.H., Y.W., S.X., J.L., B.W. and Y.B.; visualization, S.L. and M.W.; supervision, M.W. and Y.B.; project administration, Y.B.; funding acquisition, Y.B.

Funding: Most of the work was funded by grant from Tsinghua University (NO. 2017104). M. Wang is partially supported by the National Science Foundation grant to UW, NSFGEO-NERC Collaborative Research: Advancing Predictability of Sea Ice: Phase 2 of the Sea Ice Prediction Network, (SIPN2) and by the Joint Institute for the Study of the Atmosphere and Ocean (JISAO) under NOAA Cooperative Agreement NA15OAR4320063, Contribution No. 2018-0174, with the Pacific Marine Environmental Laboratory contribution number being 4868. Jiping Liu is supported by the Climate Program Office, NOAA, U.S. Department of Commerce (NA15OAR4310163).

Acknowledgments: We are very grateful to James E. Overland and Phyllis J. Stabeno for their guidance and help of outcome analysis. We are also grateful to Yanluan Lin for recommending the causal effect networks method to us. We appreciate that Marlene Kretschmer and Jakob Runge help us understand the causal effect networks algorithm and provide the TIGRAMITE software package available in https://github.com/jakobrunge/tigramite. We thank all of the data development organizations and data websites for datasets available online, including SIE and SIC from NSIDC, sea-ice volume, sea-ice thickness and ice velocity from the Polar Science Center at University of Washington, ERA-Interim reanalysis data from ECMWF, and climate index from the CPC and the Climate Impacts Group at University of Washington.

Conflicts of Interest: The authors declare no conflicts of interest. The funders had no role in the design of the study; in the collection, analyses, or interpretation of data; in the writing of the manuscript, or in the decision to publish the results.

\section{References}

1. Vaughan, D.G.; Comiso, J.C.; Allison, I.; Carrasco, J.; Kaser, G.; Kwok, R.; Mote, P.; Murray, T.; Paul, F.; Ren, J.; et al. Observations: Cryosphere. In Climate Change 2013: The Physical Science Basis. Contribution of Working Group I to the Fifth Assessment Report of the Intergovernmental Panel on Climate Change; Stocker, T.F., Qin, D., Plattner, G.-K., Tignor, M., Allen, S.K., Boschung, J., Nauels, A., Xia, Y., Bex, V., Midgley, P.M., Eds.; Cambridge University Press: New York, NY, USA, 2013; pp. 317-382, ISBN 978-1-107-05799-1.

2. Cohen, J.; Screen, J.A.; Furtado, J.C.; Barlow, M.; Whittleston, D.; Coumou, D.; Coumou, D.; Francis, J.; Dethloff, K.; Entekhabi, D.; et al. Recent Arctic amplification and extreme mid-latitude weather. Nat. Geosci. 2014, 7, 627-637. [CrossRef]

3. Cavalieri, D.J.; Parkinson, C.L. Arctic sea ice variability and trends, 1979-2010. Cryosphere 2012, 6, 881-889. [CrossRef]

4. Serreze, M.C.; Holland, M.M.; Stroeve, J. Perspectives on the Arctic's Shrinking Sea-Ice Cover. Science 2007, 315, 1533-1536. [CrossRef] [PubMed]

5. Comiso, J.C.; Parkinson, C.L.; Gersten, R.; Stock, L. Accelerated decline in the Arctic sea ice cover. Geophys. Res. Lett. 2008, 35, L01703. [CrossRef]

6. Liu, J.; Song, M.; Horton, R.M.; Hu, Y. Reducing spread in climate model projections of a September ice-free Arctic. Proc. Natl. Acad. Sci. USA 2013, 110, 12571-12576. [CrossRef] [PubMed]

7. Stroeve, J.; Holland, M.M.; Meier, W.; Scambos, T.; Serreze, M. Arctic sea ice decline: Faster than forecast. Geophys. Res. Lett. 2007, 34, L09501. [CrossRef]

8. Fetterer, F.; Knowles, K.; Meier, W.; Savoie, M.; Windnagel, A.K. Sea Ice Index, Version 3; NSIDC: National Snow and Ice Data Center: Boulder, CO, USA. Available online: https://doi.org/10.7265/N5K072F8 (accessed on 23 March 2018).

9. Stroeve, J.C.; Serreze, M.C.; Holland, M.M.; Kay, J.E.; Malanik, J.; Barrett, A.P. The Arctic's rapidly shrinking sea ice cover: A research synthesis. Clim. Chang. 2012, 110, 1005-1027. [CrossRef] 
10. Johannessen, O.M.; Bengtsson, L.; Miles, M.W.; Kuzmina, S.I.; Semenov, V.A.; Alekseev, G.V.; Nagurnyi, A.P.; Zakharov, V.F.; Bobylev, L.P.; Pettersson, L.H.; et al. Arctic climate change: Observed and modelled temperature and sea-ice variability. Tellus A 2004, 56, 328-341. [CrossRef]

11. Comiso, J.C. A rapidly declining perennial sea ice cover in the Arctic. Geophys. Res. Lett. 2002, 29, 17:1-17:4. [CrossRef]

12. Markus, T.; Stroeve, J.C.; Miller, J. Recent changes in Arctic sea ice melt onset, freezeup, and melt season length. J. Geophys. Res. 2009, 114, C12024. [CrossRef]

13. Rigor, I.G.; Colony, R.L.; Martin, S. Variations in surface air temperature observations in the Arctic, 1979-1997. J. Clim. 2000, 13, 896-914. [CrossRef]

14. Kay, J.E.; L'Ecuyer, T.; Gettelman, A.; Stephens, G.; O'Dell, C. The contribution of cloud and radiation anomalies to the 2007 Arctic sea ice extent minimum. Geophys. Res. Lett. 2008, 35, L08503. [CrossRef]

15. Schweiger, A.J.; Zhang, J.; Lindsay, R.W.; Steele, M. Did unusually sunny skies help drive the record sea ice minimum of 2007? Geophys. Res. Lett. 2008, 35, L10503. [CrossRef]

16. Graversen, R.G.; Mauritsen, T.; Drijfhout, S.; Tjernström, M.; Mårtensson, S. Warm winds from the Pacific caused extensive Arctic sea-ice melt in summer 2007. Clim. Dyn. 2011, 36, 2103-2112. [CrossRef]

17. Francis, J.A.; Hunter, E. New Insight into the Disappearing Arctic Sea Ice. EOS 2006, 87, 509-511. [CrossRef]

18. Perovich, D.K.; Light, B.; Eicken, H.; Jones, K.F.; Runciman, K.; Nghiem, S.V. Increasing solar heating of the Arctic Ocean and adjacent seas, 1979-2005: Attribution and role in the ice-albedo feedback. Geophys. Res. Lett. 2007, 34, L19505. [CrossRef]

19. Perovich, D.K.; Richter-Menge, J.A.; Jones, K.F.; Light, B. Sunlight, water, and ice: Extreme Arctic sea ice melt during the summer of 2007. Geophys. Res. Lett. 2008, 35, L11501. [CrossRef]

20. Lindsay, R.W.; Zhang, J. The thinning of Arctic sea ice, 1988-2003: Have We Passed a Tipping Point? J. Clim. 2005, 18, 4879-4894. [CrossRef]

21. Lindsay, R.W.; Zhang, J.; Schweiger, A.; Steele, M.; Stern, H. Arctic Sea Ice Retreat in 2007 Follows Thinning Trend. J. Clim. 2009, 22, 165-176. [CrossRef]

22. Maslanik, J.A.; Fowler, C.; Stroeve, J.; Drobot, S.; Zwally, J.; Yi, D.; Emery, W. A younger, thinner Arctic ice cover: Increased potential for rapid, extensive sea-ice loss. Geophys. Res. Lett. 2007, 34, L24501. [CrossRef]

23. Zhang, J.; Lindsay, R.; Steele, M.; Schweiger, A. What drove the dramatic retreat of arctic sea ice during summer 2007? Geophys. Res. Lett. 2008, 35, L11505. [CrossRef]

24. Rigor, I.G.; Wallace, J.M.; Colony, R.L. Response of sea ice to the Arctic Oscillation. J. Clim. 2002, 15, $2648-2663$. [CrossRef]

25. Thompson, D.W.; Wallace, J.M. The Arctic Oscillation signature in the wintertime geopotential height and temperature fields. Geophys. Res. Lett. 1998, 25, 1297-1300. [CrossRef]

26. Zhang, J.; Rothrock, D.; Steele, M. Recent Changes in Arctic Sea Ice: The Interplay between Ice Dynamics and Thermodynamics. J. Clim. 2000, 13, 3099-3114. [CrossRef]

27. Rigor, I.G.; Wallace, J.M. Variations in the age of Arctic sea-ice and summer sea-ice extent. Geophys. Res. Lett. 2004, 31, L09401. [CrossRef]

28. L'Heureux, M.L.; Kumar, A.; Bell, G.D.; Halpert, M.S.; Higgins, R.W. Role of the Pacific-North American (PNA) pattern in the 2007 Arctic sea ice decline. Geophys. Res. Lett. 2008, 35, L20701. [CrossRef]

29. Overland, J.E.; Wang, M. Large-scale atmospheric circulation changes are associated with the recent loss of Arctic sea ice. Tellus A 2010, 62, 1-9. [CrossRef]

30. Watanabe, E.; Wang, J.; Sumi, A.; Hasumi, H. Arctic dipole anomaly and its contribution to sea ice export from the Arctic Ocean in the 20th century. Geophys. Res. Lett. 2006, 33, L23703. [CrossRef]

31. Wang, J.; Zhang, J.; Watanabe, E.; Ikeda, M.; Mizobata, K.; Walsh, J.E.; Bai, X.; Wu, B. Is the Dipole Anomaly a major driver to record lows in Arctic summer sea ice extent? Geophys. Res. Lett. 2009, 36, L05706. [CrossRef]

32. Wu, B.; Wang, J.; Walsh, J.E. Dipole Anomaly in the Winter Arctic Atmosphere and Its Association with Sea Ice Motion. J. Clim. 2006, 19, 210-225. [CrossRef]

33. Zhang, X.; Sorteberg, A.; Zhang, J.; Gerdes, R.; Comiso, J.C. Recent radical shifts of atmospheric circulations and rapid changes in Arctic climate system. Geophys. Res. Lett. 2008, 35, L22701. [CrossRef]

34. Hilmer, M.; Jung, T. Evidence for a recent change in the link between the North Atlantic Oscillation and Arctic sea ice export. Geophys. Res. Lett. 2000, 27, 989-992. [CrossRef] 
35. Stroeve, J.C.; Maslanik, J.; Serreze, M.C.; Rigor, I.; Meier, W.; Fowler, C. Sea ice response to an extreme negative phase of the Arctic Oscillation during winter 2009/2010. Geophys. Res. Lett. 2011, 38, L02502. [CrossRef]

36. Stroeve, J.C.; Kattsov, V.; Barrett, A.; Serreze, M.; Pavlova, T.; Holland, M.; Meier, W.N. Trends in Arctic sea ice extent from CMIP5, CMIP3 and observations. Geophys. Res. Lett. 2012, 39, L16502. [CrossRef]

37. Wang, M.; Overland, J.E. A sea ice free summer Arctic within 30 years: An update from CMIP5 models. Geophys. Res. Lett. 2012, 39, L18501. [CrossRef]

38. Runge, J.; Petoukhov, V.; Donges, J.F.; Hlinka, J.; Jajcay, N.; Vejmelka, M.; Hartman, D.; Marwan, N.; Palus, M.; Kurths, J. Identifying causal gateways and mediators in complex spatio-temporal systems. Nat. Commun. 2015, 6, 8502:1-8502:10. [CrossRef] [PubMed]

39. Fetterer, F.; Knowles, K. Sea ice index monitors polar ice extent. EOS 2004, 85, 163. [CrossRef]

40. Cavalieri, D.J.; Parkinson, C.L.; Gloersen, P.; Zwally, H.J. Sea-Ice Concentrations from Nimbus-7 SMMR and DMSP SSM/I-SSMIS Passive Microwave Data, Version 1; NASA National Snow and Ice Data Center Distributed Active Archive Center: Boulder, CO, USA. Available online: https:/ /doi.org/10.5067/8GQ8LZQVL0VL (accessed on 23 March 2018).

41. Maslanik, J.; Stroeve, J. Near-Real-Time DMSP SSMIS Daily Polar Gridded Sea-Ice Concentrations, Version 1; NASA National Snow and Ice Data Center Distributed Active Archive Center: Boulder, CO, USA. Available online: https:/ / doi.org/10.5067/U8C09DWVX9LM (accessed on 23 March 2018).

42. Zhang, J.; Rothrock, D.A. Modeling Global Sea Ice with a Thickness and Enthalpy Distribution Model in Generalized Curvilinear Coordinates. Mon. Weather Rev. 2003, 131, 845-861. [CrossRef]

43. Dee, D.P.; Uppala, S.M.; Simmons, A.J.; Berrisford, P.; Poli, P.; Kobayashi, S.; Andrae, U.; Balmaseda, M.A.; Balsamo, G.; Bauer, P.; et al. The ERA-Interim reanalysis: Configuration and performance of the data assimilation system. Q. J. R. Meteorol. Soc. 2011, 137, 553-597. [CrossRef]

44. Simmons, A.; Uppala, S.; Dee, D.; Kobayashi, S. ERA-Interim: New ECMWF reanalysis products from 1989 onwards. ECMWF Newsl. 2006, 110, 25-35. [CrossRef]

45. Dee, D.P.; Uppala, S. Variational bias correction of satellite radiance data in the ERA-Interim reanalysis. Q. J. R. Meteorol. Soc. 2009, 135, 1830-1841. [CrossRef]

46. Dee, D.P.; Balmaseda, M.M.; Balsamo, G.; Engelen, R.; Simmons, A.J.; Thepaut, J.-N. Toward a Consistent Reanalysis of the Climate System. Bull. Am. Meteorol. Soc. 2014, 95, 1235-1248. [CrossRef]

47. Drobot, S.D.; Maslanik, J.A.; Fowler, C. A long-range forecast of Arctic summer sea-ice minimum extent. Geophys. Res. Lett. 2006, 33, L10501. [CrossRef]

48. Drobot, S.D. Using remote sensing data to develop seasonal outlooks for Arctic regional sea-ice minimum extent. Remote Sens. Environ. 2007, 111, 136-147. [CrossRef]

49. Lindsay, R.W.; Zhang, J.; Schweiger, A.J.; Steele, M.A. Seasonal predictions of ice extent in the Arctic Ocean. J. Geophys. Res. 2008, 113, C02023. [CrossRef]

50. Runge, J. Quantifying information transfer and mediation along causal pathways in complex systems. Phys. Rev. E 2015, 92, 062829. [CrossRef] [PubMed]

51. Runge, J.; Heitzig, J.; Petoukhov, V.; Kurths, J. Escaping the curse of dimensionality in estimating multivariate transfer entropy. Phys. Rev. Lett. 2012, 108, 258701. [CrossRef] [PubMed]

52. Ebert-Uphoff, I.; Deng, Y. Causal Discovery for Climate Research Using Graphical Models. J. Clim. 2012, 25, 5648-5665. [CrossRef]

53. Deng, Y.; Eber-Uphoff, I. Weakening of atmospheric information flow in a warming climate in the Community Climate System Model. Geophys. Res. Lett. 2014, 41, 193-200. [CrossRef]

54. Schleussner, C.F.; Runge, J.; Lehmann, J.; Levermann, A. The role of the North Atlantic overturning and deep ocean for multi-decadal global-mean-temperature variability. Earth Syst. Dyn. 2014, 5, 103-115. [CrossRef]

55. Pearl, J. Causality: Models, reasoning and inference. Econ. Theory 2003, 19, 675-685. [CrossRef]

56. Spirtes, P.; Glymour, C.; Scheines, R. Causation, Prediction, and Search, 2nd ed.; MIT Press: Cambridge, MA, USA, 2000; ISBN 0-262-19440-6.

57. Kretschmer, M.; Coumou, D.; Donges, J.F.; Runge, J. Using Causal Effect Networks to Analyze Different Arctic Drivers of Midlatitude Winter Circulation. J. Clim. 2016, 29, 4069-4081. [CrossRef]

58. Wallace, J.M.; Gutzler, D.S. Teleconnections in the geopotential height field during the Northern Hemisphere winter. Mon. Weather Rev. 1981, 109, 784-812. [CrossRef] 
59. Blanchard-Wrigglesworth, E.; Armour, K.C.; Bitz, C.M.; DeWeaver, E. Persistence and inherent predictability of Arctic sea ice in a GCM ensemble and observations. J. Clim. 2011, 24, 231-250. [CrossRef]

60. Holland, M.M.; Bailey, D.A.; Vavrus, S. Inherent sea ice predictability in the rapidly changing Arctic environment of the Community Climate System Model, version 3. Clim. Dyn. 2011, 36, 1239-1253. [CrossRef]

61. Holland, M.M.; Stroeve, J. Changing seasonal sea ice predictor relationships in a changing Arctic climate. Geophys. Res. Lett. 2011, 38, L18501. [CrossRef] 